\title{
ANALISIS SEMIOTIK ATAS SAMPUL MAJALAH TEMPO JAKARTA "RIZAL RAMLI PETARUNG ATAU PERAUNG"
}

\author{
Wildan Yusran \\ ywildan@gmail.com \\ Hanny Hafiar \\ hannyhafiar@gmail.com \\ Diah Fatma Sjoraida \\ diahfatmasjoraida@yahoo.co.id \\ Fakultas Ilmu Komunikasi Universitas Padjadajaran
}

\begin{abstract}
This study uses qualitative methods with semiotics analysis from Charles Sanders Peirce. The purposes of this study are to determine the symbol contained in MBM Tempo, the meaning contained within the symbol, and how these symbols constructing Rizal Ramli's Image as the howling. The result of this study showed MBM Tempo Jakarta cover "The Fighter or The Howling" 24-30 August 2015 Edition consist of three main symbols, Rizal Ramli's on his hips, pointing and opened mouth, a hand hold puppet stick, and text symbol. Rizal Ramli's caricature in the cover of MBM Tempo is an illustration of the text is written in the middle of Tempo's cover, so that both are interlocked. These symbols have different meanings. The meaning of each symbol constructing the image of Rizal Ramli as the howling in the cover of MBM Tempo. The conclusion of this study showed that the symbols MBM Tempo Jakarta cover "The Fighter or The Howling" 24-30 August 2015 Edition consist of three main symbols, Rizal Ramli's on his hips, pointing and opened mouth, a hand hold puppet stick, and text symbol included to typography.
\end{abstract}

\section{Abstrak}

Penelitian ini menggunakan metode kualitatif dengan analisis semiotika Charles Sanders Peirce. Tujuan penelitian ini adalah untuk mengetahui simbol yang terdapat dalam MBM Tempo, makna yang terkandung dalam simbol-simbol, dan simbol pada MBM Tempo dapat mengkonstruksi citra Rizal Ramli sebagai Peraung. Hasil penelitian menunjukkan sampul MBM Tempo Jakarta "Rizal Ramli Petarung atau Peraung" Edisi 24-30 Agustus 2015 terdiri dari tiga simbol utama, simbol gesture Rizal Ramli sedang berkacak pinggang, menunjuk dan mulut terbuka, simbol tangan wayang yang memegang tuding, dan simbol teks. Karikatur Rizal Ramli yang terdapat dalam sampul MBM Tempo merupakan ilustrasi dari teks yang tertulis ditengah sampul Tempo, sehingga keduanya saling berkaitan. Simbol-simbol tersebut memiliki makna yang berbeda-beda. Makna yang terkandung dari setiap simbol mengkonstruksikan citra Rizal Ramli sebagai Peraung dalam sampul MBM Tempo. Kesimpulan penelitian ini adalah terdapat tiga simbol utama dalam sampul MBM Tempo Jakarta "Rizal Ramli Petarung atau Peraung" Edisi 24-30 Agustus 2015, yaitu simbol gesture Rizal Ramli sedang berkacak pinggang, menunjuk, dan mulut terbuka, simbol tangan wayang yang memegang tuding, dan simbol teks yang termasuk tipografi.

Keywords: Semiotics, Charles Sanders Peirce, Magazine Cover, Tempo. 


\section{PENDAHULUAN}

Belum ada satu tahun masa kepemimpinannya, Presiden Jokowi melakukan perombakan terhadap Kabinet Kerja pada tanggal 12 Agustus 2015. Terdapat lima menteri yang masuk dalam pemerintahan Jokowi-Kalla. Isu reshuffle kabinet ini sudah berhembus sejak pertengahan tahun 2015. Menko Perekomian Sofyan Djalil digantikan oleh Darmin Nasution, Menko Polhukam Tedjo Edhy Purdjiatno digantikan oleh Luhut Binsar Panjaitan, Menko Kemaritiman Indroyono Soesilo digantikan oleh Rizal Ramli, Menteri Kepala Bappenas Andrinov Chaniago digantikan oleh Sofyan Djalil, dan Menteri Perdagangan Rahmat Gobel digantikan oleh Thomas Lembong.

Nama Rizal Ramliyang memasuki jajaran Kabinet Kerja sebagai Menteri Koordinator Kemaritiman dalam perombakan yang dilakukan Presiden Joko Widodo membuat banyak orang yang heran karena sebelumnya beliau beberapa kali melontarkan kritik keras kepada pemerintah. Menjadi pertanyaan siapakah yang "membawa” Rizal Ramli masuk ke dalam jajaran Kabinet Kerja. Rizal Ramli mengatakan bahwa dirinya tidak menjalin kontak dengan Megawati untuk menjadi menteri. Pengakuan Rizal Ramli ini sejalan dengan pernyataan Ketua Dewan Kepemimpinan Pusat PDI-P, Andreas Pareira. Menurutnya, PDI-P tidak menerbitkan surat dukungan untuk Rizal Ramli (Dikutip dari MBM Tempo edisi 24-30 Agustus 2015).

Citra Rizal Ramli yang baru menjabat menjadi Menteri Koordinator (Menko) Kemaritiman setelahadanya reshuffle Kabinet Kerja dalam kepemimpinan Presiden Jokowi tidak begitu mulus. Hal itu disebabkan oleh perilaku beliau sendiri yang baru sehari masa jabatannya sudah meminta agar PT Garuda Indonesia Tbk membatalkan pembelian 30 unit pesawat Airbus A350. Rizal Ramli menganggap pembelian Airbus A350 bakal bikin Garuda keok (Dikutip dari MBM Tempo 24-30 Agustus 2015).

Jauh sebelum kritik pedas terhadap rekannya sendiri dalam jajaran menterimenteri Kabinet Kerja, Rizal juga sering mengkritik kinerja para menteri Jokowi, terutama menteri-menteri yang membidangi ekonomi dan perdagangan. Di dalam suatu acara diskusi di Jakarta, pada 4 Februari 2015, Rizal Ramli bahkan dengan terang-terangan mengatakan bahwa banyak mentri di Kabinet Kerja Jokowi sangat tak berkualitas. Kualitasnya bukan " $k w-2$ " lagi, tetapi " $k w-3$ ". Beliau pun mencontohkan Menteri Koordinator Politik, Hukum, dan Keamanan Tedjo Edhy Purdijatno yang dianggap memperkeruh konflik antara KPK dan Polri, saat mengatakan rakyat pendukung KPK adalah rakyat yang tidak jelas.

Hal tersebut merupakan hal yang tidak lazim dan akan menimbulkan kontroversi, seseorang mengkritik orang lain dari instansinya sendiri dan diumbar pada publik. Seperti Rizal yang mengkritik Kementrian BUMN dalam rencana pembelian pesawat baru untuk maskapai Garuda Indonesia dan proyek pembangkit listrik 35.000 megawatt. Kritikan tersebut akan menimbulkan kesan tidak baik oleh masyarakat bahwa hubungan internal dalam instansi tersebut tidak baik. Dengan begitu selain menurunkan citra Rizal sendiri, beliau akan menurunkan citra dari instansi Rizal berada yaitu Kabinet Kerja Kepemerintahan.

Jokowi menyebut Rizal Ramli sebagai petarung, ia pun menyadari bahwa Rizal Ramli banyak mengkritik kebijakannya. Dugaan Jokowi ini tidak salah seluruhnya. Sebab, sehari setelah dilantiknya Rizal Ramli sebagai Menko Kemaritiman, ia memancing emosi Menteri BUMN dan mengajak duel Wakil Presiden, Jusuf Kalla.

Dalam laporan utama Majalah Berita Mingguan (MBM) Tempo, citra Rizal Ramli sebagai peraung sangat ditonjolkan karena beliau mengumbar kritik ke media dan menyerang koleganya di kabinet. Selama ini beliau memang dikenal sebagai pengkritik kerassejumlahkebijakanpemerintah. Bahkan saat menjelang akhir rapat, saat Jokowi memberi Jusuf Kalla untuk menyampaikan sambutan penutup. Rizal Ramli kembali mengangkat tangan untuk meminta waktu berbicara lagi. 
Wildan Yusran, Hanny Hafiar, dan Diah Fatma Sjoraid, Analisis Semiotik Atas Sampul Majalah Tempo ...

Rizal Ramli menuding ada pejabat yang "bermain" dalam proyek kereta api cepat Jakarta-Bandung, tudingan tersebut mendapat respon dari Alwi Hamu selaku Koordinator Staf Khusus Wakil Presiden bahwa Rizal Ramli tidak punya sopan santun. Husain Abdullah, juru bicara wakil presiden Jusuf Kalla, mengatakan tidak sepantasnya menteri menantang wakil presiden. Rini Soemarno selaku Menteri Badan Usaha Milik negara juga menanggapi raungan Rizal Ramli dengan mengatakan, "Bicara itu harus dengan dasar, jangan sembarangan.”

Peraung adalah kata yang cocok untuk RizalRamlisaatbarudiangkatmenjadiMenteri Koordinator Kemaritiman, karena beliau baru sehari dan sudah banyak mengkritik kebijakan pemerintah Jokowi. Jika beliau sudah membuktikan hasil kinerjanya sangat baikdalam kabinet ini, beliau dapatdikatakan sebagai peraung. Akan tetapi baru sehari menjabat, beliau sudah mengkritik sanasini. "BUMN itu jelas di bawah kementerian koordinator perekonomian, bukan di bawah kementerian koordinator kemaritiman. Jadi jangan ada yang mencampuri Garuda di luar kementerian koordinator perekonomian" kata Rini Soemarno.

Rizal Ramli tidak hanya kali ini bergesekan dengan Jusuf Kalla. Rizal Ramli dijegal ketika dicalonkan menjadi Menteri Keuangan atau Menteri BUMN oleh Presiden Susilo Bambang Yudhoyono di periode pertama pemerintahannya, 2004-2009. Kalla berkeras mencoret nama Rizal, yang dianggap menolak Dana Moneter Internasional (IMF). "Seorang Menteri Keuangan harus netral dan konservatif. Jadi kami cari orang yang moderat," kata Kalla waktu itu (Dikutip pada MBM Tempo edisi 24-30 Agustus 2015 halaman 32).

Terkait dengan kegaduhan dan kontroversi yang dibuat Rizal Ramli sebagai Menko Kemaritiman, Majalah Berita Mingguan (MBM) Tempo mengangkat tema tersebut menjadi laporan utama pada edisi 24-30 Agustus 2015. Dengan demikian, sampul majalah pada edisi tersebut juga menggambarkan isi laporan utamanya dengan judul "Rizal Ramli Petarung atau Peraung."

Pengertian majalah menurut KBBI adalah terbitan berkala yang isinya meliputi berbagai liputan jurnalistik, pandangan tentang topik aktual yang patut diketahui pembaca dan menurut waktu penerbitannya dibedakan atas majalah bulanan, tengah bulanan, mingguan, dan sebagainya dan menurut pengkhususan isinya dibedakan atas majalah berita, wanita, remaja, olahraga, sastra, ilmu pengetahuan tertentu, dan sebagainya.

Tipe suatu majalah ditentukan oleh sasaran khalayak yang dituju. Artinya, sejak awal redaksi sudah menentukan siapa yang akan menjadi pembacanya, apakah anakanak, remaja, wanita dewasa, pria dewasa, atau untuk pembaca umum dari remaja sampai dewasa (Ardianto, 2004: 112).

Walaupun majalah dan surat kabar samasama media massa cetak, tetapi keduanya memiliki karakteristik yang berbeda. Majalah menyajikan berita lebih dalam karena frekuensi terbit majalah yang relatif lebih lama dari surat kabar. Nilai aktualitas yang dikandung berita majalah lebih lama. Kemudian majalah meyajikan lebih banyak foto atau gambar dari surat kabar. Dan yang terakhir memiliki sampul (cover) majalah sebagai daya tarik.

Sampul majalah ibarat pakaian dan aksesorisnya pada manusia. Sampul majalah biasanya menggunakan kertas yang bagus dengan gambar dan warna yang menarik. Menarik tidaknya sampul suatu majalah sangat bergantung pada tipe majalahnya, serta konsistensi atau keajegan majalah tersebut dalam menampilkan ciri khasnya (Ardianto, 2004: 114).

Dalam sampul ini sosok Rizal Ramli dikonstruksikan dalam bentuk wayang kulit. Wayang kulit adalah wayang yang terbuat dari kulit, sehingga memiliki bayangan saat digunakan dalam pentas wayang. Wayang kulit sudah ada dari kurang lebih selama 3.478 tahun. Wayang kulit dipastikan berasal dari Indonesia, lebih tepatnya di Jawa lah dibuat peralatan wayang kulit dengan peralatan serba sederhana. 
Dalang dalam sampul ini digambarkan memiliki warna kulit lebih gelap dari Rizal Ramli. Tangan kiri dalang yang menggerakan wayang Rizal Ramli. Dalamilmu perdalangan, para raksasa dan keluarga Kurawa diletakan di sisi sebelah kiri dalang (http://www. disparbud.jabarprov.go.id/wisata/ensiklodet.php?id=5o\&lang=id diakses pada 25 Oktober 2015 pukul 23.29) Wayang yang diletakan di sisi kiri dalang, digerakan pula oleh tangan kiri dalang seperti yang tergambar dalam sampul ini.

Kurawa merupakan seratus sosok bersifat jahat. Kurawa selalu bermusuhan dengan Pandawa (lima pahlawan dalam dunia perwayangan). Kurawa bertindak kejam, licik dan mengingkari aturan yang ada di Negara Astina, sehingga bisa mengambil alih kekuasaan negara tersebut. Salah satu kurawa yang terkenal adalah Citrayudha. Citrayudha digambarkan memiliki bibiryang sangat lebar karena sifatnya lucu, banyak akal, pandai bicara dan suka mencela. Penggambaran fisik Citrayudha mirip dengan apa yang ada dalam kariaktur sampul Tempo edisi 24-30 Agustus 2015.

Sejak jaman primitif, manusia telah menggunakan bahasa tubuh untuk mengekspresikan suatu maksud. Dalam perkembangannya, kita dapat mengelompokkan hal itu ke dalam beberapa kelompok, salah satunya bahasa tubuh. Biasanya seseorang yang gelisah akan menunjukkan gerakangerakan tubuh yang memperlihatkan gejala kegelisahannya. Demikian juga seorang perempuan yang mencoba menarik perhatian seorang pria akan menunjukkan gerakangerakan bahasa tubuh yang memberi isyarat bahwa ia bersedia didekati pria tersebut (Kusrianto, 2007: 7).

Karikatur adalah gambar lelucon yang membawa pesan kritik sosial (Sobur, 2006:138). Menurut Sudarta, kartun adalah semua gambar humor, termasuk karikatur itu sendiri.Sedangkankarikaturadalahdeformasi berlebihan atas wajah seseorang, biasanya orang terkenal, dengan "mempercantiknya" dengan penggambaran ciri khas lahiriahnya untuk tujuan mengejek.
Karikatur Rizal Ramli dalam sampul ini digambarkan seolah-olah sedang menghardik seseorang. Pose Rizal Ramli tengah berkacak pinggang serta menunjuk menggunakan tangan kanannya serta tatapan mata yang lurus ke depan. Berkacak pinggang atau bertolak pinggang menunjukan sikap tertentu. Bahasa tubuh ini juga bisa melambangkan arogansi. Gerakan ini menunjukan keagresifan dan kesiagaan seseorang terhadap lingkungannya.

Sampul MBM TEMPO merupakan komunikasi visual dan bentuk dari pengaplikasian desain komunikasi visual. Sampul tersebut didesain oleh desainer sesuai dengan berita yang dimuat di dalam majalah tersebut. Dalam hal ini sampul merupakan bagian dari komunikasi visual. Komunikasi visual adalah komunikasi menggunakan bahasa visual di mana unsur dasar bahasa visual (yang menjadi kekuatan utama dalam penyampaian pesan) adalah segala sesuatu yang dapat dilihat dan dapat dipakai untuk menyampaikan arti, makna, atau pesan (Kusrianto, 2007: 10). Komunikasi visual mengkombinasikan seni, lambang, tipografi, gambar, grafis, ilustrasi, dan warna dalam penyampaiannya.

Dalam DKV tidakada aturan atau hukum yang baku, desainer bisa memakai sarana dan teknik dalam suatu karya secara efektif. Menurut Tom Lincy (Kusrianto, 2007: 277) ada lima prinsip utama yang bisa digunakan dalam desain, yaitu proporsi, keseimbangan, kontras, irama dan kesatuan.

Seperti penjelasan di atas, sampul majalah mencerminkan isi dari rubriklaporan utama. Dengan demikian karikatur dalam sampul majalah Tempo edisi 24-30 Agustus 2015 mengkonstruksikan majalah Tempo terhadap kegaduhan Rizal Ramli setelah diangkat menjadi Menko Kemaritiman. Karikatur ini menggambarkan ada dalang yang menggerakkan Rizal Ramli.

Sedangkan pengertian Citra menurut KBBI adalah gambaran. Dalam konteks politik pengertian citra adalah gambaran diri yang ingin diciptakan oleh seorang tokoh masyarakat. Jalaludin Rakhmat dalam Psikologi Komunikasi menyatakan bahwa: 
"Citra adalah gambaran/peta tentang realitas dan tidak sesuai dengan realitas, citra adalah dunia menurut persepsi”. (Rakhmat, 1985: 221). Citra selalu berhubungan dengan kenyataan dan merupakan kesan, perasaan dan gambaran seseorang terhadap objek. Citra inilah yang mempengaruhi suatu objek.

Dengan penjelasan di atas bahwa karikatur merupakan gambar lelucon yang membawa pesan kritik sosial, sampul majalah mencerminkan isi dari rubrik laporan utama, dan juga citra adalah gambaran diri yang ingin diciptakan, peneliti ingin mengetahui citra Rizal Ramli seperti apa yang dikonstruksikan dalam sampul MBM Tempo. Untuk itu peneliti tertarik untuk mengangkat tema "Konstruksi Citra Rizal Ramli dalam Sampul Majalah Berita Mingguan (MBM) Tempo Jakarta "Rizal Ramli Petarung atau Peraung" Edisi 24-30 Agustus 2015”

\section{KAJIAN PUSTAKA}

Bidang kajian semiotika atau semiologi mempelajari fungsi tanda dalam teks, yaitu bagaimana memahami sistem tanda yang ada dalam teks agar bisa menangkap pesan yang terkandung di dalamnya (Sobur, 2012: 106). Dengan kata lain, penggunaan kata semiologi menunjukkan pengaruh kubu Saussure, sedangkan semiotika lebih tertuju kepada kubu Peirce. Istilah semiotika maupun semiologi dapat digunakan untuk merujuk kepada ilmu tentang tanda-tanda tanpa adanya perbedaan pengertian yang tajam (Budiman, 2011: 3). Baik Saussure dan Peirce, keduanya melihat tanda sebagai pusat studi mereka (Crow, 2010: 13).

Istilah semiotikayang dimunculkan pada akhir abad ke-19 oleh filsuf aliran pragmatik Amerika, Charles Sanders Peirce, merujuk kepada "doktrin formal tentang tandatanda”. Semiotika merupakan persamaan dari semiologi atau istilah yang lebih umum digunakan (Nöth, 1995: 5). Hal yang menjadi dasar dari semiotika adalah konsep tentang tanda: tak hanya bahasa dan sistem komunikasi yang tersusun oleh tanda-tanda, melainkan dunia itu sendiri pun - sejauh terkait dengan pikiran manusia - seluruhnya terdiri atas tanda-tanda karena, jika tidak begitu, manusia tidak akan bisa menjalin hubungan dengan realitas. Semiotika mempelajari hakikat tentang keberadaan suatu tanda (Ardianto, 2014:80). Basisnya adalah pengertian tanda, yakni segala sesuatu yang secara konvensional dapat menggantikan atau mewakili sesuatu yang lain (Sobur, 2012: 102-103).

\section{HASIL DAN PEMBAHASAN}

\section{Simbol-simbol dalam Sampul MBM Tempo Jakarta}

Simbol merupakan salah satu istilah yang memiliki arti beragam. Dalam arti luas, simbol adalah sinonim dari tanda. Menurut Peircesimboladalahtandayangmenunjukkan hubungan alamiah antara penanda dengan petandanya dengan hubungan berdasarkan konvensi atau kesepakatan bersama. Simbol berhubungan dengan konsepyang ada. Dapat berkembang menjadi simbol baru dalam masyarakat berdasarkan pengalaman dan kesepakatan dari masyarakat. Simbol yang sudah ada ditambahkan dengan konsep baru akan membuat simbol baru yang nantinya akan berkembang juga. Peirce mengatakan dalam tulisannya,

"Symbols grow. They come into being by development out of other signs, particularly from likenesses or from mixed signs partaking of the nature of likenesses and symbols. We think only in signs. These mental signs are of mixed nature; the symbol-parts of them are called concepts. If a man makes a new symbol, it is by thoughts involving concepts. So it is only out of symbols that a new symbol can grow." (Peirce, 1998: 10)

Simbol-simbol yang terdapat pada sampul MBM Tempo dapat dilihat oleh pembaca. Simbol-simbol yang dikonstruksi memiliki sifat konvensi atau kesepakatan bersama. Ketika pembaca melihat sampul MBM Tempo, pembaca dapat melihat karikatur Rizal Ramliyang sedang menunjuk, berkacak pinggang, dengan mulut terbuka 
dan ada tangan yang memegang tuding yang terhubung dengan tangan Rizal Ramli yang sedang menunjuk. Citra Rizal Ramli dalam karikatur tersebut akan dikonstruksi oleh pembaca baik atau buruknya. Citra itu sendiri abstrak (intangible) dan tidak dapat diukur secara matematis, tetapi wujudnya bisa dirasakan dari hasil penilaian baik atau buruk. (Ruslan, 2014: 75).

Sampul majalah ibarat pakaian dan aksesorisnya pada manusia. Sampul majalah biasanya menggunakan kertas yang bagus dengan gambar dan warna yang menarik. Menarik tidaknya sampul suatu majalah sangat bergantung pada tipe majalahnya, serta konsistensi atau keajegan majalah tersebut dalam menampilkan ciri khasnya (Ardianto, 2004: 114). Dalam setiap sampul majalah berita mingguan Tempo, sebagian besar menggunakan karikatur untuk menarik perhatian dari pembaca. Selain untuk menarik pembaca, sampul majalah Tempo juga digunakan untuk menyampaikan kritik sosial dengan menggunakan karikatur sebagai sampul. Karikatur adalah gambar lelucon yang membawa pesan kritik sosial (Sobur, 2006: 138).

Karikatur yang terdapat pada sampul Tempo dalam MBM Tempo Jakarta "Rizal Ramli Petarung atau Peraung" Edisi 24-30 Agustus 2015, merupakan karikatur dari Rizal Ramli yang pada saat itu menjabat sebagai menteri koordinator kemaritiman. "Citra adalah gambaran/peta tentang realitas dan tidak sesuai dengan realitas, citra adalah dunia menurut persepsi”. (Rakhmat, 1985: 221). Citra Rizal Ramli terkonstruksi dalam benak pembaca MBM Tempo saat melihat sampul MBM Tempo apakah Rizal Ramli Petarung atau Peraung. Karikatur Rizal Ramli digambarkan sedang menunjuk, berkacak pinggang dengan mulut yang terbuka, terdapat tangan yang sedang memegang tuding wayang yang terhubung dengan tangan Rizal Ramli, serta terdapat teks "Petarung atau Peraung." Sedangkan simbol pakaian yang dikenakan oleh Rizal Ramli tidak termasuk karena jas memiliki makna bahwa yang mengenakan orang penting dan termasuk dalam politik. "English people identified these plain suits with political and personal liberty"(Budiman, 2011). Jas tidak berkaitan dengan citra Rizal Ramli sebagai petarung atau peraung.

Jadi, simbol-simbol yang terdapat pada sampul MBM Tempo meliputi Gesture Rizal Ramli sedang berkacak pinggang, menunjuk, dan mulut terbuka, Tangan sedang memegang tuding, dan Teks "Petarung atau Peraung”. Pembahasan mengenai gesture Rizal Ramli meliputi simbol-simbol tangan Rizal Ramli sedang menunjuk, berkacak pinggang, dan mulut terbuka. Pembahasan mengenai tangan sedang memegang tuding yang merupakan tuding dari wayang dan tangan tersebut tangan dalang. Sedangkan pembahasan teks "Petarung atau Peraung" meliputi jenis font dan penempatan teks. Adapaun pemahaman mengenai simbol dapat diperoleh melalui interaksi, hal ini sesuai dengan pernyataan "pengalaman komunikasi dapat dihasilkan dari interaksi antar individu yang melibatkan proses berbagi makna melalui simbol tertentu" (Nurtyasrini \& Hafiar, 2016)

Melihatsimbol padasampul MBM Tempo edisi 24-30 Agustus 2015, terdapat simbolsimbol yang terlihat jelas oleh pembaca. Simbol pertama yang terlihat adalah simbol Rizal Ramli sebagai wayang sedang berkacak pinggang, menunjuk, dan mulut terbuka. $A$ symbol is a sign that stands for its object by convention or agreement in specific contexts. For example, a rose is a symbol of love in some cultures. (Danesi, 2004:27). Pembaca akan menghubungkan karikatur Rizal Ramli tersebut dengan ide yang terdapat dalam benaknya. Menghubungkan karikatur dari benak pembaca dengan realita yang pernah dialami, diketahui, maupun dilihat oleh pembaca.

Gerakan tangan Rizal Ramli yang sedang berkacak pinggang, menunjuk dan mulut terbuka termasuk simbol-simbol yang menjadi satu kesatuan pada simbol Gesture Rizal Ramli. "Mind finds in its semiosic surroundings that which it is capable of constructing, partly in accord with a given set of conventions" (Merrel, 1997:26). Pemikiran dari pembaca yang meliputi pengalaman 
Wildan Yusran, Hanny Hafiar, dan Diah Fatma Sjoraid, Analisis Semiotik Atas Sampul Majalah Tempo ...

dan kenyataan yang dimiliki pembaca, dapat membuat simbol Rizal Ramli yang sedang berkacak pinggang, menunjuk dan mulut terbuka menjadi simbol kemarahan Rizal Ramli yang disepakati secara konvensional.

Peneliti melihat dalam simbol Rizal Ramli sebagai wayang tangan menunjuk ke arah atas ditujukan kepada seseorang atau sesuatu yang berada di atas. "Sometimes pointing is solely nonverbal, and pointing at others is often considered an offensive gesture" (Tubbs, 2008: 124). Tangan menunjuk merupakan gesture yang dapat membuat orang lain tersinggung. Mulut terbuka dan pose berkacak pinggang dalam karikatur tersebut melambangkan sikap Rizal Ramli dalam kabinet seperti mengkritik menterimenteri lain. Terutama mulut yang terbuka, merupakan bagian dari ekspresi wajah Rizal Ramliyangberpengaruhterhadapkomunikasi Rizal Ramli dalam sampul tempo. "In fact, facial cues are the single most important source of nonverbal communication" (Tubbs, 2008: 118). Faktanya, isyarat pada wajah adalah sumber yang paling penting dalam komunikasi nonverbal. Adapun pesan nonverbal seperti pesan proksemik, pesan gestural, pesan fasial dan pesan artifaktual sangat dipengaruhi oleh aspek kebudayaan (Utami, 2016)

Tangan menunjuk ke arah atas ditujukan kepada seseorang atau sesuatu yang berada di atas. Hal ini mempengaruhi citra Rizal Ramli yang akan dikonstruksi oleh pembaca. "The gesture is that phase of the individual act to which adjustment takes place on the part of other individuals in the social process of behavior" (Mead, 1934 dalam Nöth, 1995: 393). Gesture merupakan fase dari tindakan individu dalam menyesuaikan terhadap individu lainnya dalam proses sosial.

Simbol selanjutnya yang terdapat dalam sampul MBM Tempo edisi 24-30 Agustus 2015 yaitu, tangan yang sedang memegang tuding. Terlihat pada sampul Tempo, tuding yang terhubung dengan tangan Rizal Ramli sedang dipegang oleh tangan seseorang. Tuding sendiri merupakan simbol yang penting dalam karikatur ini. Tuding memiliki fungsi untuk menghidupkan atau menggerakkan tangan wayang, baik untuk gesture saat wayang itu bicara, saat diarikan, dan diperangkan (Diakses dari http://www. disparbud.jabarprov.go.id/wisata/ensiklodet.php?id=62\&lang=id pada tanggal 26 November 2016 pukul 17.50 WIB).

Terdapat proses berpikir dan membuat ide yang ada dalam pikiran pembaca berdasarkan pengalaman dan pengetahuan umum saat melihat simbol tangan yang sedang memegang tuding dalam sampul MBM Tempo. Masyarakat Indonesia sebagian besar mengetahui budaya pewayangan, sehingga yang terdapat dalam pemikiran pembaca bahwa gagang tersebut merupakan tuding yang dipegang oleh dalang dalam budaya pewayangan.

Komunikasi visual adalah komunikasi menggunakan bahasa visual di mana unsur dasar bahasa visual (yang menjadi kekuatan utama dalam penyampaian pesan) adalah segala sesuatu yang dapat dilihat dan dapat dipakai untuk menyampaikan arti, makna, atau pesan (Kusrianto, 2007: 10). Berdasarkan pernyataan tersebut, dapat dikatakan bahwa dalam sampul MBM Tempo ini tangan yang sedang memegang tuding memiki arti, makna, atau pesan yang ingin disampaikan oleh MBM Tempo kepada pembaca. Lebih tepatnya pesan yang dikomunikasikan dalam gambar tangan yang sedang memegang tuding, memiliki hubungan yang penting terhadap karikatur Rizal Ramli.

Hubungan tersebut yaitu tangan tersebut merupakan tangan dari dalang. Tangan dalang tersebut mengendalikan perilaku dan sifat Rizal Ramli sebagaimana fungsi dalang dalam pagelaran wayang yaitu penutur kisah kepada penonton. Dia adalah penutur kisah, penyanyi lagu, yang mengajak memahami suasana pada saat tertentu, pemimpin suara gamelan yang mengiringi, dan di atas segalanya itu, dialah pemberi jiwa pada boneka atau pelakupelaku manusianya itu (Groenendel, 1987: 6). Dalam pagelaran wayang, terdapat banyak aktor yang dimainkan oleh dalang untuk menceritakan kisah-kisah pewayangan. Aktor-aktor tersebut merupakan wayang itu sendiri. Rizal Ramli merupakan wayang yang 
sedang dikendalikan oleh tangan dalang memegang tuding yang terhubung dengan Rizal Ramli. Dalam pagelaran wayang Rizal Ramli merupakan salah satu aktor yang dikendalikan dan dimainkan oleh dalang.

Dalam kisah pewayangan masuk dan keluarnya wayang tergantung oleh dalang dalam menceritakan kisah pewayangan. Selain itu, kisah yang diceritakan oleh dalang dapat dipesan sesuai keinginan dari pemesan pagelaran wayang, tidak hanya terbatas dengan kisah Ramayana dan Mahabarata saja. Terdapat lakon yang sesuai untuk setiap suasana, sebagaimana ditunjukkan antara lain oleh Kats (1923:108-9). Ada lakon-lakon tentang perkawinan dan kelahiran, tentang panen, untuk memanggil hujan (Groenendel, 1987: 166).

Simbol selanjutnya yang terdapat pada sampul MBM Tempo edisi 24-30 Agustus 2015 adalah teks "Petarung atau Peraung". Teks "Petarung atau Peraung" berada pada tengah sampul MBM Tempo sebagai tipografi dalam komunikasi visual. Tipografi dalam konteks desain komunikasi visual mencakup pemilihan bentuk huruf, besar huruf, cara, dan teknik penyusunan huruf menjadi kata atau kalimat sesuai dengan karakter pesan yang ingin disampaikan (Tinarbuko, 2008:28). Pada bagian atas teks "Petarung atau Peraung" terdapat teks "Rizal Ramli". Dua teks tersebut saling berkaitan, teks "Rizal Ramli" menjadi penjelas tema berita utama pada MBM Tempo edisi 24-30 Agustus 2015. Sedangkan teks "Petarung atau Peraung" menjadi pelengkap terhadap teks sebelumnya. Teks "Petarung atau Peraung" dibuat tebal dan lebih besar sebagai penekanan dan lebih mudah tertangkap oleh mata dibanding dengan teks "Rizal Ramli", sehingga teks "Petarung atau Peraung" lah yang patut mendapat perhatian lebih dari pembaca sebagai judul majalah pada edisi ini.

Teks "Petarung atau Peraung" diletakkan di tengah-tengah sampul. Kata "Petarung Atau" terdapat di baris pertama, sehingga kata "Petarung" berada di bagian kiri dan kata "Peraung" berada di tengah sendiri. Teks tersebut terlihat berada di depan badan
Rizal Ramli dan tertutup sedikit oleh gambar dari tuding yang terhubung dari tangan dalang ke tangan Rizal Ramli yang sedang menunjuk. Pembaca diberi dua pilihan dalam mengartikan citra yang dikonstruksi oleh Tempo terhadap Rizal Ramli dengan menaruh teks "Petarung atau Peraung". Serif adalah bentuk tambahan pada huruf berupa kait. Typeface jenis serif muncul lebih dulu dibandingkan jenis sans serif (Tanpa serif) (Rustan, 2010: 35). Dapat dikatakan bahwa teks "Petarung atau Peraung" termasuk dalam jenis sans serif karena tidak memiliki kait pada hurufnya.

\section{Makna dari Simbol-simbol dalam Sampul MBM Tempo Jakarta}

Tangan menunjuk dan berkacak pinggang termasuk sebagai Gesture. "Words, gestures, and symbols are examples of conventional signs"(Danesi, 2002:9). Tangan menunjuk akan dimaknai oleh pembaca berarti ada seseorang atau sesuatu yang sedang ditunjuk oleh Rizal Ramli. "Pointing we see in adult conversation and storytelling is not pointing at physically present objects or location but is instead abstract pointing" (McNeill, 20o8: 40). Tidak ada seseorang maupun sesuatu yang ditunjuk oleh Rizal Ramli dalam karikatur pada sampul MBM Tempo edisi 24-30 Agustus 2015, hal abstrak tersebut terdapat hubungannya dengan sikap Rizal Ramli dalam kenyataan dan berita yang disampaikan oleh Tempo.

Menunjuk kearah atas memiliki banyak makna yang terkandung dan setiap orang memiliki pemikiran yang berbeda-beda terhadap menunjuk kearah atas. "Pointing the finger outward is an act of directing another's attention. Whether it's an accusation ("He did it!") or an instruction ("Look over there")" (Guigar, 2005: 57). Menunjuk keluar adalah tindakan untuk mengarahkan perhatian orang lain, apakah itu sebuah tuduhan ("Dia yang melakukannya!") atau suruhan ("Lihat ke sana").

Selain Guigar, Atre juga menganggap bahwa menunjuk merupakan tindakan untuk menarik perhatian terhadap sesuatu 
atau seseorang (Atre, 2016:55). Pembicara yang menggunakan jari telunjuk yang sedang menunjuk seperti Rizal Ramli dideskripsikan sebagai "Agresif", "Berperang", dan "Kasar" (Pease, 2016). Tidak dapat dikatakan bahwa Rizal Ramli berperilaku menyuruh atau menuduh sesuatu atau seseorang karena simbol tangan yang sedang menunjuk dilengkapi dan dilihat secara satu kesatuan dengan simbol lainnya yaitu, simbol tangan berkacak pinggang dan simbol mulut terbuka.

Menurut sopan santun di Jawa (dan juga Brunei) menunjuk ke arah tertentu harus dilakukan dengan jempol tangan, bukan dengan telunjuk (Uno, 2005: 51). Bagi pembaca MBM Tempo yang memiliki latar belakang belakang garis keturunan Jawa atau yang menyepakati budaya Jawa akan menganggap tangan menunjuk Rizal Ramli merupakan perilaku yang tidak sopan. Seperti mantan Presiden United States, Barrack Obama yang menunjuk menggunakan ibu jari, bukan dengan telunjuk. Bagi pengkaji budaya Indonesia, khususnya Jawa, menunjuk dengan ibu jari adalah simbol penghormatan dan menunjuk dengan telunjuk dianggap tidak sopan (Fox, dalam Kompasiana, 2014:69). Evaluasi kegiatan komunikasi dalam bentuk apapun, seharusnya melibatkan faktor budaya, hal ini sesuai dengan pernyataan: "melakukan evalusasi terhadap CSR dilihat dari aspek budaya dan karakter masyarakat" (Nassaluka, Hafiar, \& Priyatna, 2016).

Di Malaysia dan Filipina, menunjuk dengan jari telunjuk kepada orang adalah sebuah penghinaan karena gesture seperti itu hanya ditujukan pada binatang, dan orang Malaysia akan menggunakan ibu jari untuk menunjuk kepada orang atau untuk memberi tau arah (Pease, 2016). Menunjuk secara langsung pada seseorang secara dipahami secara universal sebagai gesture sindiran, terkadang sebagai cara untuk menunjukkan agresi. Karena indeks menunjuk dengan jari telunjuk merupakan simbol dari senjata, saat ditujukan kepada seseorang akan seperti sedang menuduh atau mengancam (Reiman, 2007: 126).
Tangan yang berkacak pinggang berhubungan dengan tangan sedang menunjuk. Berkacak pinggang sendiri memiliki maknanya sendiri yang disepakati bersama dalam masyarakat Indonesia. Ada kode-kode yang disepakati untuk mewakili perasaan tertentu, misalnya menggaruk kepala jika bingung, menggoyangkan kaki jika senang, berkacak pinggang jika marah, menunjuk dengan tangan kiri ketika mengusir, dan seterusnya (Pramayoza, 2013: 104). Dengan begitu, makna yang dapat dikonstruksi oleh pembaca terhadap gesture berkacak pinggang yaitu karikatur Rizal Ramli sedang marah.

Direktur IMF bertolak pinggang/ berkacak pinggang pada 15 Januari 1998 di Jakarta, pada saat penandatanganan LoI (Letter of Intent) oleh presiden Soeharto, adegan ini merupakan suatu simbol dari kecenderungan IMF untuk berperan sebagai seorang "guru" yang sedang mendisiplinkan "anak nakal" (Hadiwinata, 2002: 206). Berkacak pinggang juga dinilai seperti sedang mengajari sesuatu atau seseorang yang ditunjuk oleh Rizal Ramli. "Standing with hands on hips is an attempt to maintain dominance or intimidate others" (Reiman, 2007: 132). Tangan berkacak pinggang merupakan percobaan untuk menjaga kekuasaan atau mengintimidasi orang lain. Banyak orang tua yang akan melakukan hal ini saat menghadapi anak dengan kelakuan yang buruk.

Simbol selanjutnya yaitu simbol mulut terbuka pada wajah Rizal Ramli. Mulut merupakan bagian dari wajah yang berpengaruh pada ekspresi Rizal Ramli sedang melakukan apa. Simbol ini berhubungan dengan dua simbol sebelumnya untuk mendapatkan makna dari simbol Rizal Ramli sebagai wayang sedang berkacak pinggang, menunjuk dengan mulut terbuka yang dikonstruksi oleh Tempo pada sampul MBM Tempo edisi 24-30 Agustus 2015. Menurut Poespoprodjo, (2004: 128). Simbol merangsang manusia untuk mengadakan refleksi sehingga mengawali setiap pemikiran religius, filsafat, dan ilmu. Simbol senantiasa harus dapat diberi arti dan interpretasi baru 
(Permana, 2015.). Sisi lain dari bahasa tubuh melibatkan ekspresi wajah, sikap badan, gerak isyarat, dan nada suara yang Anda pakai ketika Anda marah atau mau menjadi marah, beberapa tanda marah antara lain: Alis mata terangkat, sikapyang kaku, ngomel, menunjuk seseorang, dan berkacak pinggang (McKay \& Dinkmeyer : 103).
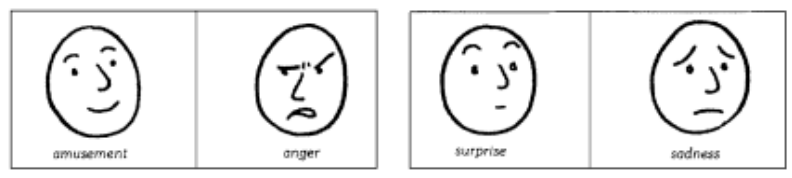

\section{Gambar 1 Gambar Ekspresi Marah.}

Sumber: Marcel Danesi 2004: 50.

Dalamilmukarikatur, mulutyangterbuka biasanya menjadi ciri ekspresi kemarahan, seperti simbol mulut terbuka pada karikatur Rizal Ramli yang menandakan Rizal Ramli sedang marah. "In anger the corners of the mouth are drawn downward, and very often the teeth are visible as in the ilustration" (Smith, 2013: 31). Dalam kemarahan sudut mulut tertarik kebawah, dan sering gigi akan terlihat seperti pada ilustrasi. Seseorang atau sesuatu yang ditunjuk oleh Rizal Ramli berhubungan dengan mulut terbuka yang menandakan bahwa Rizal Ramli sedang marah. Pose Rizal Ramli yang sedang marah menunjukkan bahwa kemarahan dapat menimbulkan pertengkaran seperti dalam rapat paripurna kabinet di Istana Kepresidenan Jakarta pada Rabu, 19 Agustus 2015.

Disebutkan sebelumnya dalam simbol Rizal Ramli sebagai wayang pada sampul MBM Tempo terdapat tuding yang terhubung pada tangan Rizal Ramli. Tuding tersebut berhubungan dengan simbol selanjutnya yaitu simbol tangan memegang tuding. Tangan tersebut merupakan tangan dalang, karena tuding terdapat pada wayang dan dalang lah yang bertugas mengendalikan wayang.

"The dhalang is the primary performer throughout most of the eighthour event. He controls the flow of the performance while seated behind a light source and screen onto which he casts the shadows of puppets while telling the story chosen for the evening - often one crafted with reference to Javanese versions of the Indic Mahabharata and Ramayana" (Weiss, 2006: 5).

Dalang adalah pemain utama dalam delapan jam acara. Dia mengontrol alur kinerja sembari duduk di belakang sumber cahaya dan layar ke mana dia menampilkan bayangan dari wayang sembari menceritakan cerita yang dipilih untuk malam itu biasanya dengan merujuk pada versi Jawa dari Mahabharatadan Ramayana India. The dalang is the dominant member of the wayang golek troupe, both within and outside performance. He manipulates all the puppets, delivers the majority of the narration and dialogue, and sings many song during performance. Dalang adalah anggota dominan dari rombongan wayang golek, baik dalam dan luar pentas. Dalang memanipulasi semua boneka wayang, menyampaikan narasi dan dialog, serta menyanyikan banyak lagu saat pentas (Weintraub, 2004: 42).

Mula-mula kepala keluarga lah yang mempertunjukkan bayang-bayang. Tetapi lambat-laun merupakan fungsi tersendiri dari satu kelas tertentu yang memiliki sifatsifat khusus dan patuh. Perkembangan dan perluasan lebih lanjut dari permulaan sarana pentas yang sangat primitif (tabir, boneka, lampu dan sebagainya), peralatan mana segera ditetapkan oleh tradisi termasuk persyaratan yang suci. Demikianlah akhirnya pertunjukan ini sampai di tangan orang yang (kemudian) disebut dalang (Mulyono, 1989: 46).

Terlihat pada sampul Tempo, tuding yang terhubung dengan tangan Rizal Ramli sedang dipegang oleh tangan seseorang. Dalam karikatur Rizal Ramli dapat dikatakan bahwa Rizal Ramli hanyalah boneka/wayang atau aktor karena terdapat tuding yang terhubung dengan tangan menunjuknya. Tuding sendiri merupakan simbol yang penting dalam karikatur ini. Tuding memiliki fungsi untuk menghidupkan atau menggerakkan tangan wayang, baik untuk gesture saat wayang itu bicara, saat diarikan, dan diperangkan (Diakses dari http://www. disparbud.jabarprov.go.id/wisata/ensiklo- 
det.php?id=62\&lang=id pada tanggal 26 November 2016 pukul 17.50 WIB).

Untuk menyambung tangan dilengkapi tuding agar tangan wayang tersebut dapat bergerak sesuai dengan kehendak dalang (Mujiyat, 2002).

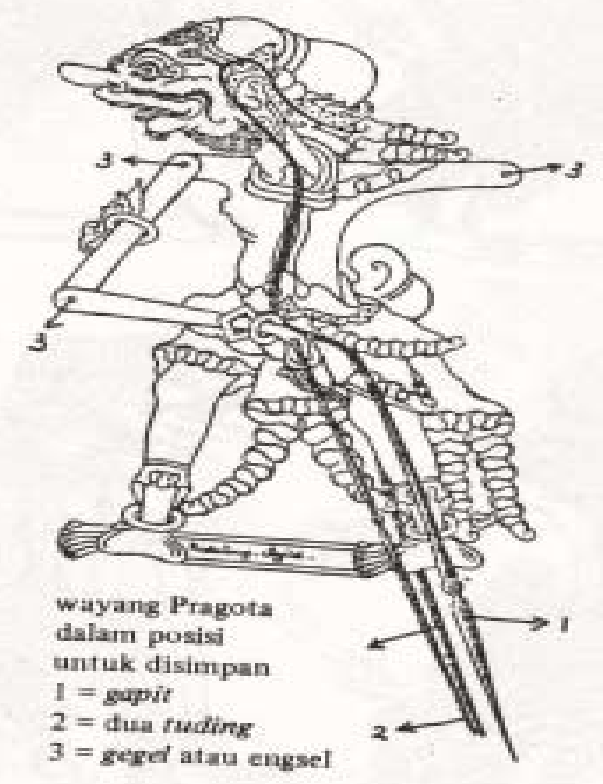

Gambar 2. Bagian-bagian wayang. Sumber:

https://wayangpustakao2.files.wordpress.

$$
\text { com/2014/o6/ }
$$

Rizal Ramli dalam karikatur yang digambarkan pada sampul MBM Tempo terhubung dengan tuding pada kedua tangannya, bisa dipastikan Rizal Ramli merupakan boneka wayang dalam cerita wayang. Terdapat dua jenis wayang yang cukup dikenal masyarakat, yaitu wayang golek dan wayang kulit. Baik wayang golek dan wayang kulit, dua duanya memiliki asal-usul yang sama, yakni wayang purwa. Dalam hal ini yang dimaksudkan dengan perkataan "wayang purwa" dalam tulisan ini adalah pertunjukan wayang yang ceritanya bersumber pada Mahabarata dan Ramayana (Mulyono, 1989: 5). Karikatur Rizal Ramli memiliki ciri-ciri mulut terbuka, hidung pesek, mata juling, dan rambut agak botak sesuai dengan tokoh wayang kulit yang bernama Sarawita/Bilung.
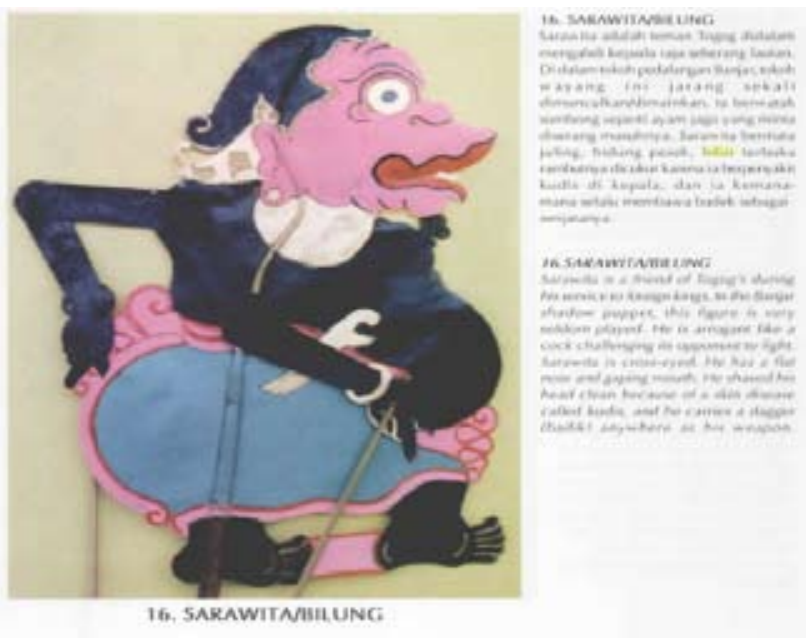

Gambar 3. Sarawita/Bilung (Mujiyat, 2002: 21)

Bilung merupakan sahabat Togog yang menjadipembantuatau pengikut para raksasa atau tokoh-tokoh yang berkepribadian jahat. Ia pun sering berganti-ganti majikan, setelah majikannya yang lama tewas di tangan ksatria. Sifatnya penakut dan cengeng. Namun ia kerap menyombongkan diri seolaholah pemberani. Ke mana-mana Sarawita senantiasa membawa senjatanya, yaitu senderik atau cundrik (Komandoko, 2009). Bilang merupakan tokoh dari pertunjukkan wayang. Pada umumnya, bahwa semua orang menganggap pertunjukkan wayang bukanlah semata-mata sesuatu yang dangkal, melainkan mempunyai arti keagamaan atau sesuatu upacara yang berhubungan dengan kepercayaan(Mulyono,1989:44).Pertunjukan wayang kulit itu semula merupakan acara keagamaan atau upacara untuk memuja "Hyang" (Roh) dikerjakan diwaktu malam hari dengan mengambil cerita-cerita dari leluhur atau nenek moyangnya seorang medium yang kemudian disebut syaman atau dikerjakan sendiri oleh kepala keluarga.

Sikap wayang dalam pagelaran wayang pada pokoknya bisa dibedakan ke dalam tiga corak utama, yaitu halus atau alus, gagak, dan kasar; disini terutama dilukiskan dalam sikap tangan yang berlain-lainan (Groenendael, 1987: 245). Dalang memegang tuding dari wayangtujuannyauntukmengendalikansikap wayang dalam cerita. Simbol tangan wayang yang memegang tuding ini mengendalikan sikap Rizal Ramli yang termasuk sikap kasar. Sikap kasar merupakan sikap yang negatif. 


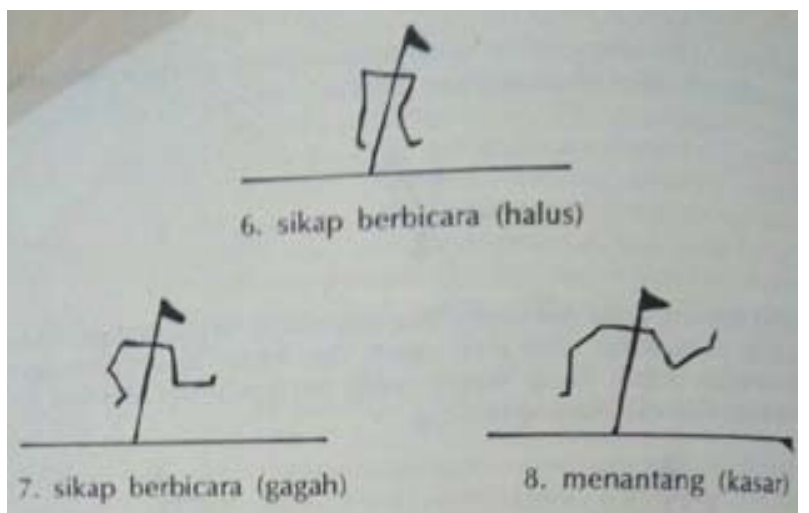

Gambar 4. Sikap wayang (Groenendael, 1987:246).

Pada MBM Tempo edisi 24-30 Agustus 2015 terdapat sampul majalah dengan karikatur Rizal Ramli dan Teks "Petarung atau Peraung”. Selain foto atau karikatur sebagai sampul, pembaca juga dapat mengetahui berita utama dari MBM Tempo, terdapat teks yang juga sama pentingnya dengan foto atau karikatur. Teks akan membuat pembaca menginterpretasi isi "Laporan Utama" dalam MBM Tempo edisi 24-30 Agustus 2015 dan pembaca akan memilih untuk mengintrepetasikan citra pada sosok Rizal Ramli "Petarung atau Peraung."

Bagi seorang desainer, yang seharihari menggunakan berbagai elemen desain (termasuk tipografi) dalam karyanya untuk mengkomunikasikan suatu pesan ke masyarakat (Rustan, 2010). Dilihat dari sisi pembuat karikatur dan MBM Tempo sendiri terdapat pesan yang ingin dikomunikasikan kepada pembaca, pesan yang ingin dikomunikasikantersebut melalui konstruksi Tempo terhadap Rizal Ramli sendiri melalui karikatur dan melalui teks "Petarung atau Peraung”. Tempo ingin mengkomunikasikan kepada pembaca bahwa terdapat dua sisi yang ada pada Rizal Ramli yaitu, "Petarung" atau "Peraung". "Petarung atau Peraung" sendiri merupakan kata yang digunakan oleh Tempo untuk menggambarkan sifat pada karikatur Rizal Ramli dalam sampul Tempo. Karikatur Rizal Ramli yang sedang berkacak pinggang, menunjuk dan mulut terbuka berhubungan dengan teks yang digunakan oleh Tempo. Pembaca akan memiliki ide terhadap sifat Rizal Ramli yang lebih cocok untuk dipilih. Sifat yang digunakan oleh Tempo baik Rizal
Ramli sebagai petarung atau Rizal Ramli sebagai peraung setelah pembaca melihat karikatur Rizal Ramli yang berpose sedang berkacak pinggang, menunjuk dan mulut terbuka, dan membaca teks "Petarung atau Peraung".

Dalam komunikasi visual tidak lepas dari yang namanya tipografi, yang dalam konteks komunikasi visual mencakup pemilihan bentuk huruf, besar huruf, cara, dan teknik penyusunan huruf menjadi kata atau kalimat sesuai dengan karakter pesan yang ingin disampaikan (Tinarbuko, 2008: 28). Jika dilihat pada sampul MBM Tempo, Teks "Petarung atau Peraung" tidak sejajar tetapi "Petarung" terletak disebelah kiri dan "Peraung" di tengah-tengah sampul. Huruf atau layout yang sudah didesain dengan perhitungan yang sangat akurat dan dibentuk dengan sangat indah belum tentu menjamin efektifitasnya sebagai penyampai pesan (Rustan, 2010: 74).

\section{Konstruksi Makna Simbol pada sampul Majalah Berita Mingguan (MBM) Tempo Rizal Ramli "Petarung atau Peraung"}

Dalam mencari makna yang terkandung dalam simbol-simbol pada sampul MBM Tempo edisi 24-30 Agustus 2015 diatas, peneliti dapat melihat bagaimana makna dalam simbol-simbol MBM Tempo yang mengkonstruksi citra Rizal Ramli "Petarung atau Peraung”. Hasil konstruksi citra dari simbol gesture Rizal Ramli sedang berkacak pinggang, menunjuk dan mulut terbuka, simbol tangan memegang tuding, dan teks "Petarung atau Peraung" dalam MBM Tempo ini merupakan pesan utama yang divisualisasikan melalui karikatur dan tulisan (Teks).

Peirce mengembangkan tipologi yang terperinci mengenai tanda, dimulai dengan klasifikasi triadik dari tanda yang berhubungan dengan representamen, objek, dan interpretan hingga ke tiga trikotomi (Nöth, 1995: 44). Simbol Rizal Ramli sebagai wayang sedang menunjuk dan berkacak pinggang dengan mulut terbuka jika dianalisis dengan Triadic Charles Sanders Peirce, terdapat tiga kategori trikotomi, yaitu kepertamaan, 
Wildan Yusran, Hanny Hafiar, dan Diah Fatma Sjoraid, Analisis Semiotik Atas Sampul Majalah Tempo ...

kekeduaan, dan keketigaan. Masingmasing kategori trikotomi terbagi menjadi representamen objek, dan interpretan.

Pada kategori kepertamaan, representamen pada simbol gesture Rizal Ramli sedang berkacak pinggang, menunjuk dan mulut terbuka adalah 'Rizal Ramli sedang menunjuk dan berkacak pinggang dengan mulutterbuka'danobjeknyaadalah'seseorang atau sesuatu'. Interpretan berkaitan dan merupakan mediasi antara representamen dan objek semiotik (Merrel, 1997: 5). Dengan begitu, interpretan pada simbol gesture Rizal Ramli berkacak pinggang, menunjuk dan mulut terbuka pada kategori kepertamaan adalah 'Rizal Ramli sedang menunjuk dan berkacak pinggang dengan mulut terbuka kepada seseorang atau sesuatu."

Pada kategori kekeduaan, simbol gesture Rizal Ramli sedang berkacak pinggang, menunjuk dan mulut terbuka. Gesture tersebut ditujukan ke arah atas' dan objeknya adalah 'Seseorang atau sesuatu tersebut membuat Rizal Ramli Marah'. Interpretan pada simbol Rizal Ramli pada kategori kekeduaan adalah 'Rizal Ramli sedang menunjuk dan berkacak pinggang dengan mulut terbuka merupakan gesture marah yang ditujukan kepada seseorang yang berada diatas'.

Padakategori keketigaan, representamen pada simbol gesture Rizal Ramli sedang berkacak pinggang, menunjuk dan mulut terbuka adalah 'Pose Rizal Ramli mengarah keatas sehingga ada yang dikonstruksi pada perilaku Rizal Ramli' dan objeknya adalah 'Seseorang atau sesuatu membuat Rizal Ramli marah ditandai dengan menunjuk, berkacak pinggang dan mulut terbuka menimbulkan pertengkaran'. Interpretan pada simbol gesture Rizal Ramli sedang berkacak pinggang, menunjuk dan mulut terbuka pada kategori keketigaan adalah 'Gesture Rizal Ramli sedang menunjuk dan berkacak pinggang dengan mulut terbuka, mengkonstruksi perilaku Rizal Ramli dipertengkaran dengan seseorang atau sesuatu yang berada diatas'.

Bagi pembaca, terdapat dua pilihan citra yang dikonstruksi oleh MBM Tempo. "Mind finds in its semiosic surroundings that which it is capable of constructing, partly in accord with a given set of conventions" (Merrel, 1997: 26). Pemikiran dari pembaca yang meliputi pengalaman dan kenyataan yang dimiliki pembaca, dapat membuat simbol gesture Rizal Ramli sedang berkacak pinggang, menunjuk dan mulut terbuka menjadi simbol yang disepakati/konvensional bahwa citra Rizal Ramli yang dikonstruksi dari simbol Rizal Ramli sebagai wayang bukanlah sifat "Petarung".

Pada kategori kepertamaan simbol tangan sedang memegang tuding dalam sampul majalah, representamen pada simbol tangan sedang memegang tuding adalah 'tangan sedang memegang tuding' dan objeknya adalah 'tangan dalang. Interpretan pada simbol tangan sedang memegang tuding pada kategori kepertamaan adalah 'Tangan yang sedang memegang tuding tersebut merupakan tangan dari dalang."

Pada kategori kekeduaan simbol tangan sedang memegang tuding dalam sampul majalah, representamen pada simbol tangan sedang memegang tuding adalah 'tangan sedang memegang tuding wayang' dan objeknya adalah 'tangan dalang digunakan untuk menggerakkan wayang. Interpretan pada simbol tangan sedang memegang tuding pada kategori kekeduaan adalah 'Dalam menggerakkan wayang, tangan dalang memegang tuding pada wayang."

Pada kategori keketigaan simbol tangan sedang memegang tuding dalam sampul majalah, representamen pada simbol tangan sedang memegang tuding adalah 'Tangan yang sedang memegang tuding dapat mengendalikan wayang' dan objeknya adalah 'Tangan dalang sebagai penggerak wayang dapat mengatur sifat dan perilaku wayang. Interpretan pada simbol tangan sedang memegang tuding pada kategori keketigaan adalah 'Tangan dalang memegang tuding wayang dapat mengendalikan wayang, termasuk sifat dan perilaku dari wayang dari awal hingga akhir cerita."

Makna dari simbol Teks "Petarung atau Peraung” merupakan simbol pelengkap untuk membuat konstruksi citra Rizal Ramli 
dalam sampul MBM Tempo, citra pada sifat Rizal Ramli yang akan dipilih oleh pembaca, sehingga pesan yang ingin dikomunikasikan dalam mengkonstruksi citra tidak akan meluas, hanya terbatas pada "Petarung atau Peraung". Dalam komunikasi visual tidak lepas dari yang namanya tipografi, yang dalam konteks komunikasi visual mencakup pemilihan bentuk huruf, besar huruf, cara, dan teknik penyusunan huruf menjadi kata atau kalimat sesuai dengan karakter pesan yang ingin disampaikan (Tinarbuko, 2008: 28).

Selain itu teks "Petarung atau Peraung" tidak sejajar tetapi "Petarung" terletak disebelah kiri dan "Peraung" di tengahtengah sampul. Kata "Peraung" diletakkan ditengah dan tidak sejajar dengan "Petarung" memiliki makna bahwa kata "Peraung" lebih penting dari pada "Petarung" yang diletakkan di pinggir. Pesan yang ingin dikomunikasikan dalam sampul MBM Tempo dalam peletakkan tersebut adalah kata "peraung" lebih terpusat daripada "petarung". Pesan yang dikomunikasikan dalam konstruksi teks tersebut selaras dengan simbol-simbol sebelumnya bahwa citra Rizal Ramli yang ingin disampaikan adalah Rizal Ramli sebagai "Peraung".

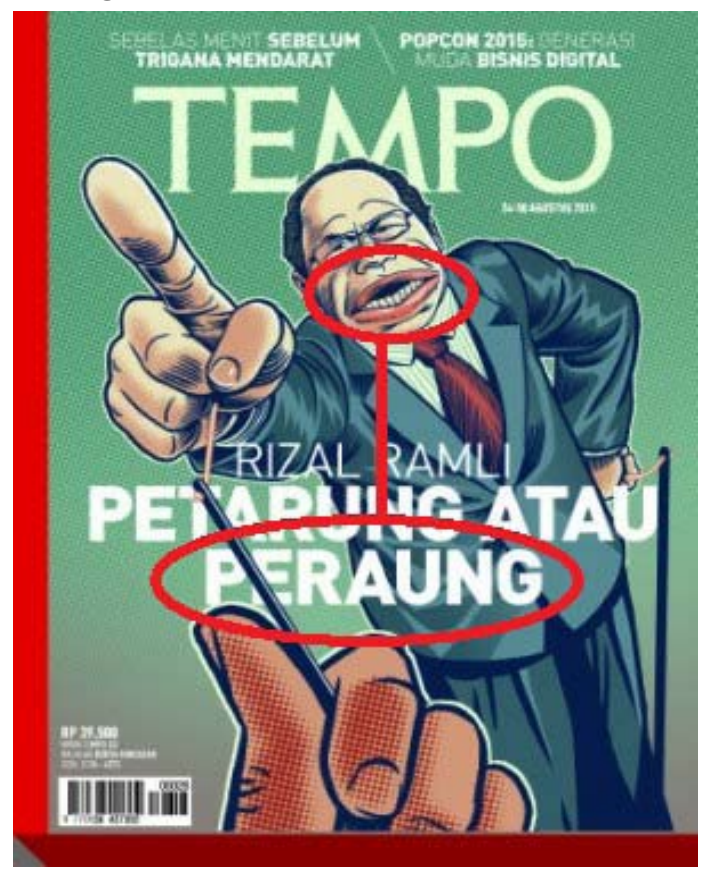

Gambar 5 Teks "Peraung” sejajar dengan Mulut Rizal Ramli.
Pada kategori kepertamaan dari simbol Teks dalam sampul majalah, representamen pada simbol teks adalah 'Petarung atau Peraung.' dan objeknya adalah 'Rizal Ramli'. Interpretan pada simbol teks pada kategori kepertamaan adalah 'Rizal Ramli Petarung atau Peraung."

Pada kategori kekeduaan dari simbol Teks dalam sampul majalah, representamen pada simbol teks adalah 'Petarung atau peraung merupakan kata yang dikonstruksi dalam sampul tempo' dan objeknya adalah 'Gesture Rizal Ramli sedang berkacak pinggang, menunjuk dan mulut terbuka merupakan sifat peraung. Interpretan pada simbol teks pada kategori kekeduaan adalah 'Gesture Rizal Ramli yang sedang berkacak pinggang, menunjuk, dan mulut terbuka adalah sifat yang dikonstruksi dalam sampul Tempo."

Pada kategori keketigaan dari simbol Teks dalam sampul majalah, representamen pada simbol teks adalah 'Petarung atau peraung menjadi pilihan menentukan kata mana yang lebih cocok.' dan objeknya adalah 'Gesture Rizal Ramli sedang berkacak pinggang, menunjuk dan mulut terbuka merupakan sifat petarung atau peraung. Interpretan pada simbol teks pada kategori keketigaan adalah 'Peraung merupakan sifat yang dikonstruksikan untuk dipilih dengan gesture Rizal Ramli yang sedang berkacak pinggang, menunjuk dan mulut terbuka." Dalam simbol-simbol yang telah dimaknai dan dikonstruksi, citra Rizal Ramli yang dikonstruksi oleh MBM Tempo adalah Rizal Ramli sebagai peraung pada cover sebuah majalah sebagai salah satu jenis dari literasi visual yang merupakan sebuah proses yang berkesinambungan yang dapat menumbuhkan pengetahuan yang dimiliki oleh masyarakat (Miftah, Rizal, \& Anwar, 2016)

\section{SIMPULAN}

Berdasarkan hasil penelitian dan pembahasan pada bab sebelumnya, maka dapat ditarik beberapa kesimpulan sebagai berikut: Simbol-simbol yang terdapat pada Sampul MBM Tempo terbagi menjadi tiga 
kategori simbol utama, yaitu Gesture Rizal Ramli sebagai wayang yang sedang berkacak pinggang, menunjuk, dan mulut terbuka sebagai kemarahan Rizal Ramli. Tangan yang sedang memegang tuding mengendalikan perilaku Rizal Ramli. Teks "Petarung atau Peraung", kata "Petarung" yang positif dan "Peraung" yang negatif.

Simbol-simbol pada sampul MBM Teтро memiliki makna masing-masing. Simbol yang pertama adalah simbol gesture Rizal Ramli sebagai wayang yang sedang berkacak pinggang, menunjuk, dan mulut terbuka. Simbol ini menggambarkan pose Rizal Ramli sedang menunjuk dan berkacak pinggang dengan mulut terbuka, memiliki makna bahwa perilaku Rizal Ramli sedang berada dipertengkaran dan marah kepada seseorang atau sesuatu yang berada di atas. Simbol yang kedua adalah simbol tangan sedang memegang tuding. Simbol tangan tersebut merupakantangandaridalang dalam pewayangan. Simbol tangan wayang sedang memegang tuding menggambarkan bahwa tangandalangyang memegang tudingwayang dapat mengendalikan wayang, termasuk sifat dan perilaku dari awal hingga akhir cerita. Simbol yang ketiga adalah teks "Petarung atau Peraung" yang menggambarkan bahwa petarung atau peraung merupakan sifat yang dikomunikasikan untuk dipilih dengan pose Rizal Ramli yang sedang menunjuk, berkacak pinggang, dengan mulut terbuka.

Ketiga simbol utama tersebut terkonstruksi dan memiliki makna yang akan dibentuk oleh pembacanya terhadap citra Rizal RamlipadasampulMBM Tempo. Maknamakna yang terkandung di dalam simbolsimbol yang terdapat dalam karikatur Rizal Ramli, pembaca dapat mengartikulasikan ide mengenai sampul MBM Tempo bahwa dalam ilmu karikatur dan komunikasi visual. Gesture Rizal Ramli sedang menunjuk, berkacak pinggang, dengan mulut terbuka merupakan perilaku sedang memarahi seseorang atau sesuatu yang berada diatas sehingga tidak sesuai dengan sifat petarung. Perilaku tersebut dikendalikan oleh dalang dalam simbol tangan sedang memegang tuding. Makna yang didapat dalam teks "Petarung atau Peraung" memperjelas bahwa citra yang ingin dikonstruksikan oleh MBM Tempo terhadap Rizal Ramli merupakan Rizal Ramli sebagai "Peraung”.

Berdasarkan hasil penelitian, pembahasan, dan kesimpulan yang telah diuraikan, maka peneliti menyarankan beberapa hal sebagai berikut: Sebaiknya karikatur dalam sampul MBM Tempo mencerminkan dari isi Laporan Utama yang terdapat dalam MBM Tempo, yaitu konflik yang terjadi Rizal Ramli dengan Jusuf Kalla dan menteri lainnya saat rapat Kabinet setelah sehari menjabat menjadi Menko Kemaritiman. Bukan dengan menampilkan sifat dari Rizal Ramli "Petarung atau Peraung" saja. Dengan cara menambahkan karikatur Jusuf Kalla atau menteri lain yang berkonflik dengan Rizal Ramli. 


\section{DAFTAR PUSTAKA}

Ardianto, Elvinaro., Lukiati Komala, dan Siti Karlinah. (2004). Komunikasi Massa: Suatu Pengantar. Bandung: Simbiosa Rekatama Media.

Atre, Sandeep. (2016). Observing Nonverbal Behaviour. New Delhi: Educreation Publishing.

Ardianto, Elvinaro. (2014). Metodologi Penelitian untuk Public Relations. Bandung: Simbiosa Rekatama Media.

Budiman, Kris. (2011). Semiotika Visual: Konsep, Isu, dan Problem Ikonisitas. Yogyakarta: Jalasutra.

Crow, David.(2010). VisibleSigns. Switzerland: AVA Publishing SA.

Danesi, Marcel. (2004). Message, signs, and Meanings: A Basic Textbook in Semiotics and Communication Theory. Toronto: Canadian Scholars' Press Inc.

Danesi, Marcel. (2002). Understanding Media Semiotics. New York: Arnold, a member of the Hodder Headline Group.

Guigar, Brad J. (2005). The Everything Cartooning Book: Create Unique and Inspired cartoons for fun and profit. U.S.A: Adams Media.

Groenendael, Victoria M. Clara. (1987). Dalang Dibalik Wayang. Jakarta: Pustaka Utama Grafiti.

Hadiwinata, Bob S. (2002). Politik Bisnis Internasional. Yogyakarta: Penerbit Kanisus.

Kusrianto, Adi. (2007). Pengantar Desain Komunikasi Visual. Yogyakarta: Penerbit Andi.

Komandoko, Gamal (2009). Bharatayudha: Banjir Darah di Tegal Kurusetra. Yogyakarta: Narasi.

Kompasiana. (2014). Kami Tidak Lupa Indonesia. Yogyakarta: PT Bentang Pustaka.
McKay, Gary., Don Dinkmeyer. How You Feel is Up To You. Jakarta: PT Grasindo.

McNeill, David. (2008). Gesture and Thought. Chicago and London: University of Chicago Press.

Merrell, Floyd. (1997). Peirce, Signs, and Meaning. Toronto, Ont.: University of Toronto Press.

Miftah, M. N., Rizal, E., \& Anwar, R. K. (2016). Pola Literasi Visual Infografer Dalam Pembuatan Informasi Grafis ( Infografis ). Jurnal Kajian Informasi Dan Perpustakaan, 4(1), 87-94.

Mujiyat., Koko Sondari. (2002). Album Wayang Kulit Banjar. Jakarta.

Mulyono, Sri. (1989). Wayang: Asal-Usul, Filsafat, dan Masa Depannya. Jakarta: PT Karya Unipres.

Nassaluka, E. U., Hafiar, H., \& Priyatna, C. C. (2016). Model Kemitraan Pt. Holcim Indonesia Tbk. Jurnal Profesi Humas, 1(1), 22-34.

Nöth, Winfried. (1995). Handbook of Semiotics. Bloomington: Indiana University Press.

Nurtyasrini, S., \& Hafiar, H. (2016). Pengalaman Komunikasi Pemulung Tentang Pemeliharaan Kesehatan Diri Dan Lingkungan Di Tpa Bantar Gebang. Jurnal Kajian Komunikasi, 4/2(8), 219228.

Pease, Allan., Barbara Pease. (2016). The Definitive Book of Body Language. London: An Orion Ebook.

Peirce, Charles Sanders (c. 1894). "What is A Sign?" in The Peirce Edition Project (ed) (1998) The Essential Peirce, selected philosophical writings. Volume 2 (1893 - 1913). Bloomington, IN, USA: Indiana University Press. pp. 4- 10.

Permana, R. S. M. (2015). Makna Tri Tangtu Di Buana Yang Mengandung Aspek Komunikasi Politik Dalam Fragmen Carita Parahyangan. Jurnal Kajian Komunikasi, Volume 3,(23), 173-191 
Wildan Yusran, Hanny Hafiar, dan Diah Fatma Sjoraid, Analisis Semiotik Atas Sampul Majalah Tempo ...

Pramayoza, Dede. (2013). Dramaturgi Sandiwara: Potret Layar Teater Populer dalam Masyarakat Poskolonial. Yogyakarta: Penerbit Ombak.

Rakhmat, Jalaluddin. (1985). Psikologi Komunikasi. Bandung: PT. Remaja Rosdakarya.

Reiman, Tonya. (2007). The Power of Body Language: How to Succeed In Every Bussiness and Social Encounter. New York: Pocket Books.

Ruslan, Rosady. (2014). Manajemen Public Relations $\mathcal{E}$ Media Komunikasi. Jakarta: PT Raja Grafindo Persada.

Rustan, Surianto. (2010). Huruf, Font, dan Tipografi. Jakarta: PT Gramedia Pustaka Utama.

Smith, Mitchell. (2013). The Art of Caricaturing. Chicago: Frederick J. Drake \& Co.

Sobur, Alex. (2006). Semiotika Komunikasi. Bandung: PT. Remaja Rosdakarya.
Sobur, Alex. (2012). Analisis Teks Media. Bandung: PT. Remaja Rosdakarya.

Tinarbuko, Sumbo. (2008). Semiotika Komunikasi Visual. Yogyakarta: Jalasutra.

Tubbs, Steward., Silvya Moss. (2008). Human Communication: Principles and Contexts. New York: McGraw-Hill.

Uno, Mien R. (2005). Etiket: Sukses Membawa diri di segala kesempatan. Jakarta: PT Gramedia Pustaka Utama.

Utami, Y. S. (2016). Pola Komunikasi Etnis Arab Dan Etnis Sunda Dalam Perkawinan Mut'ah Di Kecamatan Pacet Kabupaten Cianjur. Jurnal Kajian Komunikasi, 4/1, 75-83.

Weintraub, Andrew N. (2004). Power Plays: Wayang Golek Puppet theater of West Java.Singapore: Centerfor International Studies Ohio University.

Weiss, Sarah. (2006). Listening to An Earlier Java. Leiden: KITLV Press. 
